\title{
A descriptive study of 16 severe Plasmodium vivax cases from three municipalities of Colombia between 2009 and 2013
}

\author{
Anthony T O’Brien ${ }^{\dagger}$, Jesica F Ramírez ${ }^{\dagger}$ and Sandra P Martínez ${ }^{*}$
}

\begin{abstract}
Background: Plasmodium vivax, the most geographically distributed cause of malaria, accounts for more than $70 \%$ of cases in the Americas. In Colombia, P. vivax was responsible for $67.3 \%$ of cases in the last five years. Despite vivax malaria impact worldwide, historically it has been neglected and considered to be a benign disease. In the last decade medical literature reports have emerged countering this benign outlook. This study pretends to describe the clinical and paraclinical profile of severe vivax malaria cases hospitalized in Tumaco, Cali, Buenaventura between 2009 and 2013, to contribute to the knowledge regarding the behaviour and clinical expression of this disease.

Methods: This is a descriptive, retrospective case-series study of 16 severe malaria vivax cases, hospitalized between 2009 and 2013, in Colombian municipalities of Tumaco, Buenaventura and Cali. Severe malaria vivax cases were defined using criteria adapted from the national guidelines. Descriptive analyses of reason for consultation, signs and symptoms, diagnosis, treatment, paraclinical characteristics, complications, and time hospitalized, were conducted.

Results: Sixteen cases of severe P. vivax were analysed. Fever, chills and headache were shown to be the main admission symptoms. Elevation of total bilirubin levels in $18.75 \%$, and severe thrombocytopaenia in $25 \%$ of cases were the main complications presented during hospitalization. All cases responded to treatment, there were no deaths.

Conclusions: The following questions derived from this study could be the basis for future research: 1) Does the time to consultation have an impact on the number of days hospitalized and how cases progress during hospitalization, 2) Are the severity criteria in WHO guidelines sensitive enough to be used in clinical practice compared to national guidelines, and 3) How does malnutrition contribute to anaemia in malaria-endemic regions.
\end{abstract}

Keywords: Plasmodium vivax, Colombia, Severe

\section{Background}

Malaria, one of the most important parasitic diseases of the $21^{\text {st }}$ Century, is caused by parasites of the genus Plasmodium [1]. The disease significantly impacts global health; in 104 malaria-endemic countries where an estimated 207 million cases (135-287 million) and an estimated 627,000 deaths $(473,000-789,000)$ have been reported in 2012 [2].

Currently Plasmodium vivax is the most geographicallydistributed cause of malaria worldwide. Although, estimates vary, it is projected that 2.85 billion people live at risk [3],

\footnotetext{
*Correspondence: sanmart79@gmail.com

${ }^{\dagger}$ Equal contributors

Fundación Santa Fe de Bogotá Centro de Estudios e Investigación en Salud - CEl, Carrera 7 B \# 123-90, Piso 3, Bogotá, Colombia
}

and annual infections range between 132-391 million $[4,5]$; in the Americas, about $5.5 \%$ of people are at-risk [6], and P. vivax accounts for more than $70 \%$ of cases [7]. Furthermore, in the Americas about $30 \%$ of the population of the 21 countries with active transmission are at some degree of risk; Brazil and Colombia accounted for $68 \%$ of the cases in 2011 [2].

In Colombia, approximately 27 million individuals live in areas suitable for transmission [8], and, although the mortality of the disease has diminished, the associated morbidity has remained relatively constant, with a national registry of 378,764 cases, of which 1,800 were severe in the last five years, whereas $P$. vivax was responsible for $67.3 \%$ of all cases $[2,9,10]$. 
Tumaco (Nariño state), Buenaventura and Cali (Valle state) on the Pacific coast, are the most representative sites for high intensity transmission [8]. Buenaventura is at 7 metres above the sea level, average temperature $27^{\circ} \mathrm{C}$, $6,500 \mathrm{~mm}$ annual rainfall. Cali is located at an altitude of 995 metres above sea level, on average the temperature is $23^{\circ} \mathrm{C}$, the average annual precipitation is $1,000 \mathrm{~mm}$ in most of the metropolitan area, Tumaco is located 3 metres above sea level the average temperature ranges between 26 to $28^{\circ} \mathrm{C}$, [11-13]. Buenaventura, Cali and Tumaco, have unique characteristics that make the transmission and proliferation of Plasmodium species more prominent, and are considered endemic areas of malaria.

Despite vivax malaria significant contribution towards the overall case count worldwide, historically it has been neglected and considered to run a benign disease course compared to falciparum malaria. This has led to reduced interest in research, funding, control strategies, health and socio-economic impact evaluation [5,14-17].

In the last decade, increasing reports in medical literature have emerged to globally counter the benign outlook on $P$. vivax, documenting clinical outcomes perceived to be principally of $P$. falciparum, including cerebral malaria, hydrocephalus, retinal haemorrhage, myocarditis, acute respiratory distress, pulmonary oedema, gastro-intestinal symptoms, jaundice, hepatic dysfunction, acute kidney injury, severe anaemia, neutropaenia, thrombocytopaenia, haemoglobinuria, hypoglycaemia and shock [17-24].

Data supplementing and interpreting the increase in severe vivax malaria cases are scarce, additionally, caution is required due to weighty contributory factors, such as its relapsing nature due to hypnozoites, incidental parasitaemia, co-morbidities, treatment resistance, and access to opportune healthcare [22,25].

As of $19^{\text {th }}$ March 2014, the search within the US National Library of Medicine National Institute of Health database for severe malaria due to $P$. falciparum retrieved almost seven times more abstracts than for severe malaria due to $P$. vivax. This situation highlights the urgency to investigate in depth severe malaria cases due to $P$. vivax.

Therefore, this study intends to establish the clinical and paraclinical profile of severe malaria vivax cases hospitalized in Tumaco, Cali, and Buenaventura between 2009-2013, to contribute to the knowledge regarding the behaviour and clinical expression of this disease.

\section{Methods}

\section{Study design}

This is a descriptive, retrospective case-series study of 16 severe malaria vivax cases, hospitalized between 2009 and 2013. The data were mined from medical records revised at four hospitals located in endemic areas of the Colombian states of Nariño and Valle del Cauca, covering the municipalities of Tumaco, Buenaventura and Cali.
Medical doctors were employed and trained in order to fill out a virtual instrument accessible via email. The instrument included the following information: personal identification, past medical history, history of present illness, clinical characteristics, physical examination, diagnosis, paraclinical and parasitological results on admission, treatment and case outcome.

To assure that the instrument was filled out correctly, three independent reviewers evaluated the quality of the information filled out for each medical report and provided feedback when necessary to correct discrepancies. This was carried out at least twice, before and after feedback.

Frequencies, central tendency and dispersion were calculated. Median and comparison of frequencies was used to analyse the data. Descriptive analysis was processed using STATA $^{\bullet}$ version 12.

Variables considered in the descriptive analysis were: gender, age, place of origin, duration of symptoms before admission, symptomology on admission, presence of co-morbidities, days hospitalized, vital signs on admission, thick and thin blood smear slide results, physical examination on admission, medical treatment received, initial laboratory values, parasitaemia, complications during hospitalization, pregnancy status, previous history of malaria, and prior medical attendance before admission.

\section{Case definition of severe vivax malaria}

Subjects hospitalized between 2009-2013, with diagnostic confirmation of $P$. vivax via thick blood smear slides, and with one or more of the clinical or paraclinical criteria mentioned in the Colombian national guidelines for severe malaria, were defined as cases (Table 1).

The Colombian National guidelines for severe malaria define hepatic dysfunction as transaminase values $>40$ IU. According to medical literature and the WHO malarial hepatic dysfunction is defined as an elevation of three times the upper limit of normal transaminase values $[26,27]$. An intermediate value of $>80$ IU was utilized in this study [27-29].

\section{Exclusion criteria}

Cases with sickle cell disease, viral or bacterial infections and/or other diseases that could explain the clinical presentation were excluded, as well as cases that originated from a municipality not included within the area of analysis, or cases that were transferred from another municipality to receive medical care.

Ethical approval for access to patient medical history data and extraction for analysis and conversion to scientific manuscript was approved by the Ethical Committee of Hospital Fundación Santa Fe de Bogotá. 
Table 1 Criteria used to define severe malaria cases according to national guidelines

\begin{tabular}{|c|c|}
\hline Clinical criteria* & Laboratory criteria* \\
\hline 1. Loss of consciousness or profound coma & 1. Haemoglobinuria \\
\hline $\begin{array}{l}\text { 2. Prostration; extreme weakness with inability to walk or } \\
\text { sit without assistance }\end{array}$ & 2. Hypoglycaemia (<60 mg/dl) \\
\hline 3. Inability to feed oneself & 3. Metabolic acidosis (plasmatic bicarbonate $<15 \mathrm{mmol} / \mathrm{L}$ ) \\
\hline 4. Multiple seizures; more than 1 episode in 24 hours & 4. Hyperlactaemia (lactate acid $<5 \mathrm{mmol} / \mathrm{L}$ ) \\
\hline 5. Respiratory distress syndrome & 5. Severe anaemia (haemoglobin $<7 \mathrm{~g} / \mathrm{dL}$, haematocrit $<21 \%$ ) \\
\hline $\begin{array}{l}\text { 6. Circulatory collapse/shock; systolic arterial pressure } \\
<80 \mathrm{mmHg} \text { in adults and }<50 \mathrm{mmHg} \text { in children }\end{array}$ & $\begin{array}{l}\text { 6. Hyperparasitaemia ( }>50,000 \text { asexual parasites/uL) with the } \\
\text { diagnosis of } P \text {. falciparum, or mixed infection with } P \text {. vivax }\end{array}$ \\
\hline 7. Clinical jaundice with signs of vital organ failure & 7. Thrombocytopaenia $\left(<50,000 \mathrm{~mm}^{3}\right)$ \\
\hline 8. Spontaneous haemorrhage & 8. Elevated transaminase (>80 IU) \\
\hline \multirow[t]{2}{*}{ 9. Pulmonary oedema evidenced through radiography } & 9. Elevated total bilirubin (>1.5 mg/dL) \\
\hline & 10. Renal insufficiency (serum creatinine level $>1.5$ mg/dL) \\
\hline
\end{tabular}

*Ministry of Social Protection. Republic of Colombia. Public Health General Management. National Institute of Health. World Health Organization: Guideline for the integral clinical treatment of patients with Malaria. Bogotá; 2010 [41].

\section{Results}

\section{Demographic characteristics}

In total there were 16 cases of severe vivax malaria identified, 11 cases were from the municipality of Tumaco, three cases from Cali and two cases from Buenaventura. The median age was 23.5 years (range: five to 57 years). Demographic characteristics regarding the 16 cases are further detailed in Table 2 .

\section{Past medical history}

With regard to existing co-morbidities, one case had a medical history of secondary arterial hypertension, nonspecified diabetes mellitus, and cerebrovascular disease. Fifty percent $(8 / 16)$ of the cases had no previous history of malaria or blood transfusion in the previous month, and there was no data available for the remaining eight cases. Before reaching a site where medical care was available, $18.8 \%(3 / 16)$ of the cases did self-medicate. Of the three cases that self-medicated, two used paracetamol and one was unclear about which medication was used. Two of the cases were pregnant women.

\section{Signs and symptoms on admission}

The median period of time with symptoms before medical attendance was five days (range: three to 31 days). Fever and chills were the most ubiquitous symptoms, present in all cases. Headache, myalgia, arthralgia, asthenia and adynamia were the following most frequent symptoms as mentioned in Table 3. Dry cough was only present in $6.3 \%(1 / 16)$, while vomiting, was present in $25 \%(4 / 16)$ and abdominal pain in $25 \%(4 / 16)$. Urological symptoms were present in two cases. One case presented polyuria and dysuria, and one case presented dark urine. Haemorrhagic symptoms were alluded to in $12.5 \%(2 / 16)$ cases, one of the cases presented haematochezia and in the other case epistaxis. There were no referred severe neurological, otorhinolaryngological, or constitutional symptoms.

At the time of admission all the cases were alert (16/16). Out of the 16 cases, six were dehydrated, eight were hydrated and there is no register for two cases. Adequate diuresis was annotated in eight cases; data were not available for the remaining eight cases. Oral tolerance was registered in $93.75 \%$ of cases, data were not available for the remaining cases; it was also confirmed that in the 24 hours prior to the physical examination no case presented more than five emetic or diarrhoeic episodes. Out of the 16 cases, four presented hepatomegaly, and two cases had splenomegaly. Jaundice was found in five cases. No signs of severe neurological or pulmonary compromise were evident.

\section{Vital signs on admission}

The median body temperature was $37.0^{\circ} \mathrm{C}$ (range: 34.5 $39.5^{\circ} \mathrm{C}$ ), the systolic/diastolic pressures ranged between $60 / 20$ and $140 / 90 \mathrm{mmHg}$, with a median of $105 / 70$. Out of the 16 cases, the median heart rate was $89.0 \mathrm{BPM}$ (range: 70-140 BPM), and the median respiratory rate was 21.0 RPM (range: 16-32 RPM). Further information about the description of vital signs on admission is presented in Table 3.

\section{Malaria diagnosis}

Methods used to diagnose malaria involved peripheral film, both thick and thin blood smear. No other form of diagnosis techniques for malaria were utilized. P. vivax was identified for all cases (16/16). One case was diagnosed with thin blood smear while 93.8\% (15/16) were diagnosed with thick blood smears. Parasite count was registered for 15 out of 16 cases. Non-specified parasite count median was 6,720 p/uL (range: 320-36,500 p/uL). 
Table 2 Sociodemographic characteristics of the 16 severe vivax malaria cases

\begin{tabular}{lc}
\hline Age (years) & $\mathbf{n}(\%)$ \\
\hline 2 to 9 & $2(12.50)$ \\
15 to 19 & $4(25.00)$ \\
20 to 29 & $6(37.50)$ \\
30 to 39 & $1(6.25)$ \\
40 to 49 & $2(12.50)$ \\
$\geq 50$ & $1(6.25)$ \\
Sex & \\
Male & $9(56.25)$ \\
Female & $7(43.75)$ \\
Geographic region & \\
Tumaco & $11(68.75)$ \\
Buenaventura & $2(12.5)$ \\
Cali & $3(18.75)$ \\
Year & \\
2009 & $2(12.50)$ \\
2010 & $2(12.50)$ \\
2011 & $2(12.50)$ \\
2012 & $4(25.00)$ \\
2013 & $6(37.50)$ \\
Healthcare affiliation & $1(43.75)$ \\
Vubsidized & $1(81.25)$ \\
Sinculated & $1(6.25)$ \\
Occuptributive & $2(12.5)$ \\
Somet vendor & $1(6.25)$ \\
\hline
\end{tabular}

On entry a diagnostic impression of vivax malaria was made for $62.5 \%(10 / 16), 25 \%(4 / 16)$ of the cases were thought to be febrile syndrome of unknown origin, $6.3 \%$ $(1 / 16)$ gestational hypertension, and $6.3 \%(1 / 16)$ was suspected to be dengue with warning signs.

\section{Paraclinical results on admission}

All cases were evaluated with a haemogram at the time of admission. Haemoglobin median was $10.7 \mathrm{~g} / \mathrm{dL}$ (range: 6.2-15.0 g/dL;), haematocrit median was $34.2 \%$ (range: 18.1-43.6\%), platelets median value was $91,500 \mathrm{~mm}^{3}$ (range: $25,000 .-328,000 \mathrm{~mm}^{3}$ ). leucocytes median value was $5,935 \mathrm{~mm}^{3}$ (range: $2,500-10,800 \mathrm{~mm}^{3}$ ), while median for lymphocyte and neutrophil count was $37.55 \%$ (range: 6.0-69.4\%) and 49.6\% (range: $12.5-94.0 \%$ ), respectively.
Due to the retrospective nature of the study, register of renal function tests, liver function tests, and other paraclinical test are not available for all the cases. Glycaemia was measured on entry in 56.3\% (9/16) cases, transaminases were measured in 50\% (8/16), total bilirubin was measured in $25 \%(4 / 16)$ cases, creatinine was measured in $81.25 \%(13 / 16)$ cases and uri-analysis was undertaken in $68.75 \%$ of cases $(11 / 16)$.

The median blood glucose level was $109 \mathrm{mg} / \mathrm{dL}$ (range: 74-169 mg/dL), the median value for total bilirubin was four $\mathrm{mg} / \mathrm{dL}$ (range: $2-5.6 \mathrm{mg} / \mathrm{dL}$ ), alanine aminotransferase (ALT) and aspartate aminotransferase (AST) median value was 24 IU (range: $10-381 \mathrm{IU}$ ) and 29 IU (range: 21-377 IU) respectively, creatinine median value was $0.9 \mathrm{~g} / \mathrm{dL}$ (range: $0.5-1.6 \mathrm{~g} / \mathrm{dL}$ ). Out of the 11 urinalysis registered, nine were normal, one case had proteinuria and another case presented haematuria. Haemoglobinuria was not observed in any of the cases.

Further information about paraclinical results can be found in Table 4.

\section{Treatment received during hospitalization}

All prescribed medication was available for use by medical staff, and all medication administered was in accordance with the prescribed scheme. Anti-malarial treatment regimes consisted primarily of primaquine $93.8 \%(15 / 16)$ and chloroquine $87.5 \%$ (14/16), followed by clindamycin $18.3 \%(3 / 16)$, artemether-lumefantrine $12.5 \%$ (2/16), quinine $6.3 \%(1 / 16)$, and artesunate $6.3 \%(1 / 16)$. Doxycycline was not used in any of the cases. $87.5 \%(14 / 16)$ of cases received oral medication, while $12.5 \%(2 / 16)$ received treatment intravenously, after which they were switched to oral treatment. The median number of days with intravenous medication was five (range: $4-6$ days), while the median number of days on oral treatment was seven days (range: 7-20 days). Physical mediums to reduce fever were used in all cases.

\section{Hospitalization data}

The median number of days hospitalized was four (range: 1-8 days), $25 \%(4 / 16)$ of cases were treated in the intermediate care unit. Intermediate care unit cases had a higher median number of days hospitalized of 4.5 days, and ranged between four and six days hospitalized.

\section{Complications developed during hospitalization}

None of the cases presented haemoglobinuria, respiratory difficulty, altered mental status, prostration, seizures, inability to feed or hyperparasitaemia. Hyperlactataemia, metabolic acidosis and pulmonary oedema were not reported in the medical records, there was no evidence of arterial blood gases or chest $\mathrm{x}$ rays.

Nine from the 16 cases presented anaemia during hospitalization of which $22.2 \%$ (2/9) had severe anaemia, 
Table 3 Description of cases

\begin{tabular}{|c|c|c|c|c|c|c|c|c|c|c|c|}
\hline \multirow[b]{2}{*}{ Cases } & \multirow[b]{2}{*}{$\begin{array}{l}\text { Reason for } \\
\text { consultation }\end{array}$} & \multirow[b]{2}{*}{$\begin{array}{l}\text { Diagnosis } \\
\text { on admission }\end{array}$} & \multicolumn{4}{|c|}{ Vital signs on admission } & \multicolumn{4}{|c|}{ Physical examination on admission } & \multirow[b]{2}{*}{$\begin{array}{l}\text { Complications } \\
\text { during admission } \\
\text { and hospitalization }\end{array}$} \\
\hline & & & $\begin{array}{c}\text { Temperature } \\
\left({ }^{\circ} \mathrm{C}\right)\end{array}$ & $\begin{array}{l}\text { Pulse } \\
\text { (BPM) }\end{array}$ & $\begin{array}{l}\text { Respiratory } \\
\text { rate (RPM) }\end{array}$ & $\begin{array}{c}\text { Arterial Pressure } \\
\text { (Systolic/Diastolic } \\
\text { mmHG) }\end{array}$ & Hydrated & Jaundice & Hepatomegaly & Splenomegaly & \\
\hline 1 & $\begin{array}{l}\text { Fever, chills, myalgia, } \\
\text { asthenia, adynamia }\end{array}$ & Vivax malaria & 36.0 & 70 & 20 & $110 / 70$ & Yes & No & No & No & Elevated transaminase \\
\hline 2 & $\begin{array}{c}\text { Fever, chills, } \\
\text { headache, myalgia }\end{array}$ & Vivax malaria & 37.6 & 76 & 22 & $100 / 90$ & $\begin{array}{l}\text { Data not } \\
\text { available }\end{array}$ & $\mathrm{Si}$ & $\mathrm{Si}$ & No & $\begin{array}{l}\text { Acute renal failure, } \\
\text { elevated bilirubin, jaundice } \\
\text { with evidence of organ failure }\end{array}$ \\
\hline 3 & $\begin{array}{c}\text { Fever, chills, } \\
\text { headache, myalgia }\end{array}$ & $\begin{array}{l}\text { Dengue with } \\
\text { alarm signs }\end{array}$ & 37.0 & 100 & 20 & $100 / 80$ & No & No & No & No & $\begin{array}{l}\text { Spontaneous bleeding, } \\
\text { elevated transaminase } \\
\text { and bilirubin }\end{array}$ \\
\hline 4 & $\begin{array}{c}\text { Fever, chills, } \\
\text { headache, myalgia }\end{array}$ & Vivax malaria & 39.2 & 92 & 29 & $100 / 50$ & $\begin{array}{l}\text { Data not } \\
\text { available }\end{array}$ & No & $\mathrm{Si}$ & No & Elevated bilirubin \\
\hline 5 & Fever, chills, headache & Vivax malaria & 36.3 & 98 & 20 & $90 / 60$ & No & No & $\begin{array}{l}\text { Data not } \\
\text { available }\end{array}$ & $\begin{array}{l}\text { Data not } \\
\text { available }\end{array}$ & Shock, thrombocytopaenia \\
\hline 6 & $\begin{array}{c}\text { Fever, chills, headache, } \\
\text { myalgia, asthenia, } \\
\text { adynamia }\end{array}$ & Febril syndrome & 39.0 & 140 & 24 & $\begin{array}{l}\text { Data not } \\
\text { available }\end{array}$ & No & No & $\begin{array}{l}\text { Data not } \\
\text { available }\end{array}$ & $\begin{array}{l}\text { Data not } \\
\text { available }\end{array}$ & Hypoglycaemia \\
\hline 7 & $\begin{array}{c}\text { Fever, chills, } \\
\text { headache, myalgia }\end{array}$ & Vivax malaria & 37.4 & 84 & 20 & $110 / 70$ & No & $\mathrm{Si}$ & No & No & $\begin{array}{l}\text { Elevated transaminase, } \\
\text { jaundice with evidence } \\
\text { of organ failure }\end{array}$ \\
\hline 8 & Fever, chills, headache, & Febril syndrome & 39.0 & 104 & 32 & $60 / 20$ & No & No & No & No & Shock, thrombocytopaenia \\
\hline 9 & $\begin{array}{l}\text { Fever, chills, myalgia, } \\
\text { asthenia, adynamia }\end{array}$ & Vivax malaria & 34.5 & 88 & 22 & $110 / 80$ & Yes & No & No & No & Thrombocytopaenia \\
\hline $10^{*}$ & $\begin{array}{l}\text { Fever, chills, headache, } \\
\text { asthenia, adynamia }\end{array}$ & Febril syndrome & 37.0 & 100 & 22 & $100 / 60$ & Yes & No & No & No & Elevated bilirubin \\
\hline 11 & $\begin{array}{c}\text { Fever, chills, } \\
\text { asthenia, adynamia }\end{array}$ & Vivax malaria & $\begin{array}{l}\text { Data not } \\
\text { available }\end{array}$ & 80 & 19 & $110 / 70$ & Yes & $\mathrm{Si}$ & No & No & $\begin{array}{l}\text { Elevated bilirubin, } \\
\text { jaundice with evidence } \\
\text { of organ failure }\end{array}$ \\
\hline 12 & $\begin{array}{l}\text { Fever, chills, headache, } \\
\text { asthenia, adynamia }\end{array}$ & Vivax malaria & 36.5 & 90 & 18 & $100 / 50$ & Yes & $\mathrm{Si}$ & $\mathrm{Si}$ & $\mathrm{Si}$ & Shock \\
\hline 13 & $\begin{array}{c}\text { Fever, chills, headache, } \\
\text { asthenia, adynamia }\end{array}$ & Vivax malaria & 37.0 & 88 & 22 & $120 / 80$ & Yes & Si & $\mathrm{Si}$ & No & Thrombocytopaenia \\
\hline 14 & Fever, chills, headache & Vivax malaria & 37.0 & 117 & 28 & $\begin{array}{l}\text { Data not } \\
\text { available }\end{array}$ & Yes & No & $\mathrm{Si}$ & $\mathrm{Si}$ & $\begin{array}{l}\text { Spontaneous bleeding, } \\
\text { severe anaemia }\end{array}$ \\
\hline 15 & $\begin{array}{c}\text { Fever, chills, } \\
\text { headache, myalgia }\end{array}$ & Febril syndrome & 39.5 & 80 & 19 & $110 / 70$ & No & No & No & No & Elevated bilirubin \\
\hline $16^{*}$ & Fever, chills & $\begin{array}{l}\text { Gestational } \\
\text { hypertension }\end{array}$ & $\begin{array}{l}\text { Data not } \\
\text { available }\end{array}$ & 84 & 16 & $140 / 90$ & Yes & No & No & No & Severe anaemia \\
\hline
\end{tabular}

*Pregnant cases. 
Table 4 On admission paraclinical results

\begin{tabular}{|c|c|c|c|c|c|c|c|c|c|}
\hline Cases & Haemoglobin (g/dL) & Haematocrit (\%) & Platelets (mm3) & Leucocytes (mm3) & Lymphocytes (\%) & Neutrophils (\%) & $\begin{array}{c}\text { Alanine } \\
\text { transaminase (UI) }\end{array}$ & $\begin{array}{c}\text { Aspartate } \\
\text { aminotransferase (UI) }\end{array}$ & $\begin{array}{l}\text { Creatinine } \\
\text { (g/dL) }\end{array}$ \\
\hline 1 & 13.65 & 41.71 & 120,000 & 5,370 & 54.50 & 27.90 & Data not available & Data not available & 1.00 \\
\hline 2 & 14.60 & 43.60 & 169,000 & 8,880 & 20.00 & 74.70 & 38.00 & 32.00 & 1.60 \\
\hline 3 & 12.10 & 34.30 & 82,000 & 8,100 & 38.50 & 41.00 & 381 & 377 & 0.50 \\
\hline 4 & 8.80 & Data not available & 73,500 & 10,800 & 29.00 & 52.00 & Data not available & Data not available & 0.70 \\
\hline 5 & 14.83 & 41.08 & 42,000 & 5,800 & 27.60 & 59.40 & Data not available & Data not available & 0.90 \\
\hline 6 & 11.00 & Data not available & Data not available & 3,260 & 43.00 & 57.00 & Data not available & Data not available & Data not available \\
\hline 7 & 10.40 & 32.00 & 118,000 & 3,220 & 25.40 & 68.30 & Data not available & 189 & 1.10 \\
\hline 8 & 7.97 & 25.78 & 25,000 & 5,080 & 36.60 & 47.20 & 21 & 31 & 1.04 \\
\hline 9 & 11.17 & 34.20 & 47,000 & 2,500 & 50.40 & 29.10 & 23 & 29 & 0.90 \\
\hline 10 & 9.30 & 28.20 & 69,000 & 4,200 & 49.00 & 35.60 & 49 & 28 & 0.50 \\
\hline 11 & 9.99 & 29.00 & 101,000 & 3,760 & 24.00 & 62.00 & 25 & 21 & 0.70 \\
\hline 12 & 15.00 & Data not available & 105,000 & 8,500 & 6.00 & 94.00 & Data not available & Data not available & 1.00 \\
\hline 13 & 10.00 & 34.40 & 43,000 & 7,960 & 43.00 & 44.70 & Data not available & Data not available & Data not available \\
\hline 14 & 6.51 & 18.88 & 317,000 & 6,070 & 69.40 & 12.50 & Data not available & Data not available & 1.00 \\
\hline 15 & 11.36 & 35.14 & 150,000 & 10,800 & 66.00 & 25.20 & Data not available & Data not available & Data not available \\
\hline 16 & 6.20 & 18.10 & 328,000 & 8,000 & 34.80 & 58.50 & 10 & 25 & 0.80 \\
\hline
\end{tabular}


and 33.3\% (3/9) received transfusion of red blood cells. Jaundice was presented in five out of 16 cases; it was consider a severity sign in three cases due to the presence of jaundice plus signs of organ dysfunction. Further information about complication developed during hospitalization is summarized in Table 5.

\section{Discussion}

Information from medical records of sixteen cases of severe vivax malaria hospitalized in the municipalities of Tumaco, Cali, and Buenaventura, between 2009 and 2013 was collected retrospectively. The majority of the cases originated from Tumaco, one of the cases presented comorbidities that didn't seem to affect its outcome. Principal symptoms found at time of admission were fever, chills, and headache. Main complications found were: hyperbilirubinaemia, thrombocytopaenia and jaundice with evidence of organ dysfunction. Most of the cases received Chloroquine and primaquine as main treatment.

The Pacific Colombian geographic region has socioeconomic and environmental conditions able to the transmission of malaria species as described by Arevalo. et al. [8,11]. Plasmodium vivax is the most prevalent malaria parasite in Colombia, even though P. falciparum has been described as the main cause of severe malaria and malaria caused by $P$. vivax has been considered a benign condition, this outlook has been challenged in the last decade, and complications have been described [18,30].

According to the literature, cases that had malaria and one or more co-morbidities tended to develop more complications and severe presentations [24,26,31]. From the 16 cases described, only one case was diagnosed with arterial hypertension, diabetes mellitus and cerebrovascular disease. Despite the presence of co-morbidities, no

\begin{tabular}{|c|c|c|}
\hline Complications & $\mathrm{n}$ & $\%$ \\
\hline Spontaneous bleeding & 2 & 12.50 \\
\hline $\begin{array}{l}\text { Shock: Systolic pressure }<80 \mathrm{~mm} / \mathrm{Hg} \text { (adults), } \\
<50 \mathrm{mmHg} \text { (children) }\end{array}$ & 3 & 18.57 \\
\hline $\begin{array}{l}\text { Severe normocytic anaemia: Haemoglobyn } \\
<7 \mathrm{~g} / \mathrm{dL} \text {, hematocryte }<21 \%\end{array}$ & 2 & 12.50 \\
\hline Hypoglaecemia $<60 \mathrm{mg} / \mathrm{dL}$ & 1 & 6.25 \\
\hline Acute renal failure: Creatinine $>1.5 \mathrm{mg} / \mathrm{dL}$ & 1 & 6.25 \\
\hline Elevated aminotransferase $>80$ U.I. & 3 & 18.75 \\
\hline Hyperbilirubinemia: Total bilirubin $>3$ mg/dL & 6 & 37.50 \\
\hline Thrombocytopaenia $<50,000 \mathrm{~mm} 3$ & 4 & 25.00 \\
\hline Jaundice with evidence of organ dysfunction & 3 & 18.57 \\
\hline \multicolumn{3}{|l|}{ One complication $(8 / 16 ; 50.00 \%)$} \\
\hline More than one complication $(8 / 16 ; 50.00 \%)$ & & \\
\hline
\end{tabular}

evidence of any particular pattern of increased complications during hospitalization was found.

The symptoms that were mentioned by cases were concordant with symptoms most frequently mentioned in medical literature, such as fever, chills, headache, musculoskeletal pain, asthenia, and adynamia [8]. Respiratory and gastrointestinal symptoms were not as frequently mentioned by theses cases. Presence of pruritus was exclusively reported in pregnant cases, as an incidental symptom.

Of particular interest was the presence of hepatomegaly in four cases, jaundice in five cases, elevated transaminase in three cases, and elevated bilirubin values in six cases, which had been reported in the literature as common signs and laboratory values associated with a complication of vivax malaria [7,21,27,30,32].

With regard to vital signs, it was observed that the median body temperature was $37.0^{\circ} \mathrm{C}$, which is lower than expected value for a case with malaria. This may confuse diagnosis and delay treatment. Although there were only three cases that reported self-medication, data was not available for almost half of the cases (7/16); it is possible that antipyretic use prior to consultation masked the fever. A certain degree of immunity in endemic areas has also been suggested as cause of afebrile infection and low severity of symptoms [8].

Malaria diagnosis was suspected through signs and symptoms mentioned above, to confirm the diagnosis all cases underwent paraclinical evaluation through blood smear. Thick blood smear was used in 15 cases, while thin blood smear was used in one case. These methods are widely available in endemic regions in Colombia due to their low costs, despite the existence of more sensitive and specific diagnostic tests [29,33].

Additional paraclinical data were registered to complement the medical evaluation and asses malaria severity. Anaemia, thrombocytopaenia, hepatic dysfunction, acute renal failure, hypoglycemia were evidenced.

Severe anaemia is described in literature as one of the main severity complications of endemic regions [8,32]. Anaemia was found in nine of the 16 cases, two of them were considered severe anaemia (haemoglobin $<7 \mathrm{mg} / \mathrm{dL}$ ) and required blood transfusion.

Given the socio-economic conditions of the population, it is difficult to associate anaemia solely with $P$. vivax, as other factors, such as malnutrition, could have influenced the presence of anaemia [34-36]. Currently the literature on this topic in Colombia is scarce, or focused in children and thus should be studied.

Low platelet count is been considered a common complication presented in severe vivax malaria, and causal factor of mucosal bleeding [37]. 25\% of the cases had a count below 50,000 $\mathrm{mm} 3$ and only two cases reported haemorrhagic manifestations. Renal damage was found 
in one of the cases included in the study; creatinine levels were slightly above normal range, another explanation for this increment could be dehydration.

None of the cases presented signs of pulmonary oedema or acute respiratory distress syndrome, therefore, there was no indication to order chest $\mathrm{X}$ ray to rule out the complication. Müller et al. consider the low rate of pulmonary signs to be a result of cases residing in an endemic region, where they develop protective immunity, reducing these pulmonary complications $[7,27]$.

Hepatic dysfunction, represented principally as an elevation of total bilirubin value, was the foremost salient criterion for diagnosis of severe vivax malaria. As described in the literature, elevation of bilirubin has been associated with anaemia and thrombocytopaenia $[27,29,38]$. In this study $25 \%$ of cases presented anaemia and elevated bilirubin levels.

According to the World Health Organization (WHO) international guidelines [39], hepatic complication was present in two cases; one case had total bilirubin levels above $3 \mathrm{mg} / \mathrm{dl}$, and had a three fold elevation of transaminase normal value while the other case only presented total bilirubin levels greater than $3 \mathrm{mg} / \mathrm{dl}$.

In agreement with the literature, the WHO criteria are too demanding, resulting in a low detection sensitivity $[28,40]$. Additionally, the national guideline criteria of abnormal hepatic dysfunction are 3,5 times more sensitive than the WHO criteria. For this reason, it was decided to utilize an intermediate value for transaminase values of 80 IU to classify abnormal hepatic dysfunction [28]. No cases presented with acute hepatic failure as defined by King's College criteria [41].

With regard to treatment, all prescribed medications were available and administered in a timely manner. In Colombia, the first-line treatment for non-severe malaria is chloroquine and primaquine. Despite reports of resistance since 2001, it appears to be effective for vivax infection [42-44]. The first-line treatment for severe malaria is intravenous artesunate, followed by combined oral treatment artemether and lumefantrine. Pregnant women should receive combined treatment with quinine and clindamycin [42].

Chloroquine and primaquine were the most prescribed medications, $93.8 \%(15 / 16)$ and $87.5 \%(14 / 16)$, respectively, which suggests that the cases are being treated as non-severe malaria. Clindamycin was prescribed in three cases and quinine was prescribed in one case; the two pregnant cases did not receive medication indicated by national guidelines. Artemether-lumefantrine was only prescribed for two cases and only one of the cases received artesunate. All cases received antipyretic and crystalloids during hospitalization. Other forms of medication received included gastric mucosal protective agents, followed by analgesics and then diuretics.
Despite chloroquine and primaquine not being recommended in national guidelines for severe $P$. vivax cases, there was a notable reduction of symptoms and disease progression, which was related to a positive outcome in all cases.

Limitations of the study include quantity, distribution of cases obtained, which did not represent the established rates of infection in Colombia or reported vector behaviour. The retrospective nature of the design of the study used to collect data was a limitation within itself. Most of the medical records reviewed were handwritten; only in 2013 were the majority of visited hospitals beginning to utilize electronic medical records. This limited the mining of data due to the high proportion of incomplete, fractionated or illegible medical records before 2013, thus explaining in part the concentration of data in 2013.

In agreement with Tobón, et al., the fact that cases seek medical attendance at different stages of the disease could imply that some symptoms of severity might be present while others are not at the time of admission [27]. This could have led to different approaches towards case diagnosis, treatment and paraclinical examination possibly explaining the disparity in data between cases.

\section{Conclusion}

This retrospective case-series of 16 hospitalized cases of vivax malaria was written to contribute to the knowledge regarding the behaviour and clinical expression of this disease. A predominance of fever, chills and headache as admission symptoms was evidenced, and an elevation of total bilirubin levels, and severe thrombocytopaenia were the main complications presented during hospitalization. All cases responded to treatment, there were no deaths. Questions arising from this study that can be followed up to include: 1) If the time to consultation has an impact on the number of days hospitalized and how cases progress during hospitalization 2) If the severity criteria in WHO guidelines is sensitive enough to be used in clinical practice, versus national guidelines, and 3) If there is a particular role that malnutrition contributes to in malaria-endemic regions that suffer from anaemia.

\section{Abbreviations}

ICU: Intermediate care units; BUN: Blood urea nitrogen; WHO: World Health Organization; ALT: Alanine aminotransferase; AST: Aspartate aminotransferase; BPM: Beats per minute; RPM: Respirations per minute; IU: International units.

\section{Competing interests}

The authors declare that they have no competing interests.

\section{Authors' contributions}

SPM conceived the study. JFR gathered the necessary information. ATO and JFR carried out the statistical analysis. SPM, ATO and JFR interpreted the results. ATO drafted the manuscript, while ATO and JFR collaborated on the discussion and conclusion. ATO, JFR and SPM revised critically important intellectual content. SPM managed the critical revision of the manuscript. ATO and JFR helped interpret and reviewed the manuscript. ATO adapted the manuscript for the journal. All authors read and approved the final manuscript. 


\section{Acknowledgements}

This study was funded by the Administrative Department of Science, Technology, and Innovation (Colciencias-Grant 537/2011). We thank Dr B Porras for her expertise and guidance in the construction of this study.

Received: 14 July 2014 Accepted: 10 October 2014 Published: 15 October 2014

\section{References}

1. Grillet ME, El Souki M, Laguna F, León JR: The periodicity of Plasmodium vivax and Plasmodium falciparum in Venezuela. Acta Trop 2014 129:52-60.

2. World Health Organization: World Malaria Report. Geneva: World Health; 2012.

3. Guerra CA, Snow RW, Hay SI: Mapping the global extent of malaria in 2005. Trends Parasitol 2006, 22:353-358.

4. Hay SI, Guerra CA, Tatem AJ, Noor AM, Snow RW: The global distribution and population at risk of malaria: past, present and future. Lancet Infect Dis 2004, 4:327-336.

5. Price RN, Tjitra E, Guerra CA, Yeung S, White NJ, Anstey NM: Vivax malaria: neglected and not benign. Am J Trop Med Hyg 2007, 77:79-87.

6. Guerra C, Howes RE, Patil AP, Gething PW, Van Boeckel TP, Temperley WH, Kabaria CW, Tatern AJ, Manh BH, Elyazar IRF, Baird JK, Snow RW, Hay SI: The international limits and population at risk of Plasmodium vivax transmission in 2009. PLoS Negl Trop Dis 2010, 4:e774.

7. Mueller I, Galinski MR, Baird JK, Carlton JM, Kochar DK, Alonso PL, del Portillo HA: Key gaps in the knowledge of Plasmodium vivax, a neglected human malaria parasite. Lancet Infect Dis 2009, 9:555-566.

8. Arevalo-Herrera M, Quiñones ML, Guerra C, Céspedes N, Giron S, Ahumada M, Piñeros JG, Padilla N, Terrientes Z, Rosas A, Padilla JC, Escalante AA, Beier $J C$, Herrera S: Malaria in selected non-Amazonian countries of Latin America. Acta Trop 2012, 121:303-314.

9. National Health Institute: Official Surveillance Bulletin on Malaria in Colombia. Bogotá: INS; 2012. Viewed at: http://www.ins.gov.co/lineas-de-accion/ Subdireccion-Vigilancia/sivigila/Estadsticas\%20SIVIGILA/CASOS\%20POR\% 20EVENTO\%202012\%20FINAL.pdf.

10. National Health Institute: Official Surveillance Bulletin on Malaria in Colombia Epidemiological Week 50. Bogotá: INS; 2013. Viewed at: http://www.ins.gov. co/lineas-de-accion/Subdireccion-Vigilancia/sivigila/Estadsticas\%20SIVIGILA/ TABLAS_2013_A_SEM\%2052.pdf.

11. Official website of Tumaco (Nariño), Colombia. http://www.tumaco-narino. gov.co/informacion_general.shtml.

12. Official website of Cali (Valle del Cauca), Colombia. http://www.cali. gov.co-/publicaciones/datos_de_cali_y_el_valle_del_cauca_pub.

13. Official website of Buenaventura (Valle del Cauca), Colombia. http:// www.buenaventura.gov.co/categorias/2/1/informacion-general.

14. Picot S: Is Plasmodium vivax still a paradigm for uncomplicated malaria? Med Mal Infect 2006, 36:406-413.

15. Sina B: Focus on Plasmodium vivax. Trends Parasitol 2002, 18:287-289.

16. Baird JK: Neglect of Plasmodium vivax malaria. Trends Parasitol 2007, 23:533-539.

17. Pinzón MA, Pineda JC, Rosso F, Shinchi M, Bonilla-Abadía F: Plasmodium vivax cerebral malaria complicated with venous sinus thrombosis in Colombia. Asian Pac J Trop Med 2013, 6:413-415.

18. Kute VB, Goswami JG, Vanikar AV, Shah PR, Gumber MR, Patel HV, Trivedi HL: Unusual presentation of Plasmodium vivax: a neglected human malaria parasite. Parasitol Res 2012, 110:2573-2576.

19. Mehmood A, Ejaz K, Ahmed T: Severity of Plasmodium vivax malaria in Karachi: a cross-sectional study. J Infect Dev Ctries 2010, 6:664-670.

20. Rizvi I, Tripathi DK, Chughtai AM, Beg M, Zaman S, Zaidi N: Complications associated with Plasmodium vivax malaria: a retrospective study from a tertiary care hospital based in Western Uttar Pradesh, India. Ann Afr Med 2013, 12:155-159.

21. Ketema T, Bacha K: Plasmodium vivax associated severe malaria complications among children in some malaria endemic areas of Ethiopia. BMC Public Health 2013, 13:637.

22. Costa FTM, Lopes SCP, Albrecht L, Ataíde R, Siqueira AM, Souza RM, Russell B, Renia L, Marinho CR, Lacerda MV: On the pathogenesis of Plasmodium vivax malaria: perspectives from the Brazilian field. Int J Parasitol 2012, 42:1099-1105.
23. Antinori S, Milazzo L, Ridolfo AL, Galimberti L, Corbellino M: Severe Plasmodium vivax malaria: fact or fiction? Clin Infect Dis 2012, 55:1581-1583

24. Gupta N, Sahoo SK: Plasmodium vivax induced myocarditis: a rare case report. Indian J Med Microbiol 2013, 31:180-181.

25. Price RN, Douglas NM, Anstey NM: New developments in Plasmodium vivax malaria: severe disease and the rise of chloroquine resistance. Curr Opin Infect Dis 2009, 22:430-435.

26. Bhalla A, Suri V, Singh V: Malarial hepatopathy. J Postgrad Med 2006, 52:315-320.

27. Tobón-Castaño A, Giraldo-Castro C, Blair S: Prognostic value of clinical and parasitological signs for severe malaria in patients from Colombia. Biomedica 2012, 32(Suppl 1):79-94.

28. Piñeros JG, Tobon-Castaño A: Maternal clinical findings in malaria in pregnancy in a region of northwestern Colombia. Am J Trop Med Hyg 2013, 89:520-526.

29. Arboleda M, Pérez MF, Fernández D, Usuga LY, Meza M: Clinical and laboratory profile of Plasmodium vivax malaria patients hospitalized in Apartadó, Colombia. Biomedica 2012, 32(Suppl 1):58-67.

30. Lacerda MV, Mourão MP, Alexandre MA, Siqueira AM, Magalhães BM, Martinez-Espinosa FE, Filho FS, Brasil P, Ventura AM, Tada MS, Couto VS, Silva $A R$, Silva RS, Alecrim MG: Understanding the clinical spectrum of complicated Plasmodium vivax malaria: a systematic review on the contributions of the Brazilian literature. Malar J 2012, 11:12

31. Anstey NM, Russell B, Yeo TW, Price RN: The pathophysiology of vivax malaria. Trends Parasitol 2009, 25:220-227.

32. Singh $H$, Parakh A, Basu S, Rath B: Plasmodium vivax malaria: is it actually benign? J Infect Public Health 2011, 4:91-95.

33. Andrade BB, Reis-Filho A, Barros AM, Souza-Neto SM, Nogueira LL, Fuku-Tani KF, Camargo EP, Camargo LM, Barral A, Duarte A, Barral-Netto M: Towards a precise test for malaria diagnosis in the Brazilian Amazon: comparison among field microscopy, a rapid diagnostic test, nested PCR, and a computational expert system based on artificial neural networks. Malar J 2010, 9:117.

34. Uscátegui RM, Correa AM, Carmona-Fonseca J: Cambios en las concentraciones de retinol, hemoglobina y ferritina en niños palúdicos colombianos. Biomedica 2009, 29:270-281.

35. Carmona-Fonseca J: Malaria, desnutrición y parasitosis intestinal en los niños colombianos: interrelaciones. latreia 2004, 17:354-369.

36. Quintero JP, Siqueira AM, Tobón A, Blair S, Moreno A, Arévalo-Herrera M, Lacerda MV, Valencia SH: Malaria-related anaemia: a Latin American perspective. Mem Inst Oswaldo Cruz 2011, 106:91-104.

37. Rodriguez-Morales AJ, Sanchez E, Vargas M, Piccolo C, Colina R, Arria M, Franco-Paredes C: Occurrence of thrombocytopenia in Plasmodium vivax malaria. Clin Infect Dis 2005, 41:130-131

38. Andrade BB, Reis-Filho A, Souza-Neto SM, Clarencio J, Camargo LM, Barral A Barral-Netto M: Severe Plasmodium vivax malaria exhibits marked inflammatory imbalance. Malar J 2010, 9:13.

39. World Health Organization: Management of Severe Malaria: a Practical Handbook, Third Edition. Geneva: World Health Organization; 2012.

40. Tobón A, Piñeros J, Trujillo S, Carmona-Fonseca J: Clinical presentation of severe malaria due to Plasmodiun falciparum. Case control study in Tumaco and Turbo (Colombia). latreia 2006, 19:4.

41. O'Grady JG, Alexander GJ, Hayllar KM, Williams R: Early indicators of prognosis in fulminant hepatic failure. Gastroenterology 1989, 97:339-345.

42. Ministry of Social Protection. Republic of Colombia. Public Health General Management. National Institute of Health. World Health Organization: Guideline for the Integral Clinical Treatment of Patients With Malaria. Bogotá: Pan American Health Organization; 2010.

43. Fernando D, Rodrigo C, Rakapakse S: Primaquine in vivax malaria: an update and review on management issues. Malar J 2011, 10:351.

44. Ríos A, Álvarez G, Blair S: Ten years of chloroquine efficacy for uncomplicated Plasmodium vivax malaria treatment, Turbo, Antioquia 2002 and 2011. Biomedica 2013, 33:429-438.

doi:10.1186/1475-2875-13-404

Cite this article as: O'Brien et al:: A descriptive study of 16 severe Plasmodium vivax cases from three municipalities of Colombia between 2009 and 2013. Malaria Journal 2014 13:404. 